\title{
Linking hydrologic regime, rainfall and leaf litter fall in a riverine forest within the Ramsar Site Humedales Chaco (Argentina)
}

\author{
Sylvina L. Casco, ${ }^{1,2 *}$ María E. Galassi, ${ }^{2}$ Eliana K. A. Mari, ${ }^{2}$ Alicia S. G. Poi ${ }^{1,2}$ and Juan J. Neiff ${ }^{1}$ \\ ${ }^{1}$ Centro de Ecología Aplicada del Litoral, Consejo Nacional de Investigaciones Científicas y Técnicas, Ruta 5, Km 2.5, C.C. 291, Corrientes 3400, Argentina \\ ${ }^{2}$ Universidad Nacional del Nordeste, Corrientes, Argentina
}

\begin{abstract}
The input of leaf litter from riparian vegetation could be affected by changes in precipitation and modifications to the hydrological regime. We analyse the pattern of leaf litterfall at the community scale as well as the breakdown rate in a mixed gallery forest that covers the levees of the Paraná River oxbow lake. Litterfall was collected biweekly for 4 years that represents different rainfall and hydrologic regimes of the Paraná River including flood and prolonged drought: 1996-1997 (PA), 1999-2000 (PB), $2005-2006$ (PC) and 2007-2008 (PD). To analyse leaf breakdown, litter bags were incubated on the forest floor during flooding conditions (FFo) and dry conditions (DFo) and in the oxbow lake (FOx). The total annual leaf litterfall were 8.97, 11.15, 10.42 and $14.43 \mathrm{tn} \mathrm{ha}^{-1} \mathrm{yr}^{-1}$ for PA, PB, PC and PD, respectively. Our results suggest that with the increasing severity of the dry season and decreasing hydrologic connectivity, the annual leaf litterfall increases, whereas its seasonal pattern does not change. Regardless of the seasonal pattern of rainfall and hydrological regime in each study period, leaf fall occurred throughout the year, and the peak was recorded between August and October. Leaves decomposed fastest in FOx, and the leaf breakdown on the forest floor was slower during flooding conditions than in dry conditions. Regular floods are natural occurrences that do not affect the leaf production of the Paraná mixed forest, and the leaf processing depends on the oxygen concentrations. Prolonged droughts led to high annual leaf production, which is mainly processed within this forest. Copyright (C) 2015 John Wiley \& Sons, Ltd.
\end{abstract}

KEY WORDS leaf breakdown; leaf production; Paraná River; South America; subtropical riverine forests

Received 7 October 2014; Revised 31 July 2015; Accepted 1 August 2015

\section{INTRODUCTION}

Leaf litter accounts for $72 \%$ of the total litter production in riparian deciduous forests and appears to be related to the total net production of aboveground biomass (Naiman et al., 2005). In temperate regions, most of the litter input to streams is seasonal (Graça, 1993; Pozo et al., 1997), occurring mainly in autumn, although lateral input may also occur throughout the year (Allan and Castillo, 2007). In tropical forests, the timing of leaf fall is more variable because trees are in mixed associations that respond to factors other than temperature and day length. Water scarcity, torrential rainstorms, floodplain inundation and human activities such as fire contribute large numbers of leaves to the floodplain (Wantzen et al., 2008). Thus, litter fall in this forest may be either seasonal, when a marked dry season occurs o may be nonsynchronous, with litter entering streams evenly over the entire year (Abelho, 2001).

\footnotetext{
*Correspondence to: Sylvina L. Casco, Centro de Ecología Aplicada del Litoral (CONICET-UNNE), Ruta 5, Km 2.5, C.C. 291, Corrientes 3400, Argentina. E-mail: sylvina.casco@gmail.com
}

Hydrology is the primary factor governing biogeochemical processes (Tabacchi et al., 1998) and tree diversity in riverine wetlands (Budke et al., 2010; de Assis and Wittmann, 2011; Marchetti and Aceñolaza, 2012). Periodic flooding provides an adequate water supply for the vegetation and contributes to the higher productivity of riverine forests (Brinson, 1990; Mitsch and Gosselink, 1993). However, the subsidy-stress hypothesis does not adequately describe patterns of productivity in floodplain forests because conditions of periodic flooding do not often lead to high rates of productivity (Megonigal et al., 1997).

The magnitude, frequency, duration and timing of the inundation phase influence the amount of litterfall (Conner et al., 1981; Naiman et al., 2005) and the decomposition process (Langhans and Tockner, 2006). Drying and wetting alter the quality and physico-chemical conditions of litter, thus affecting the decomposition process (Tockner et al., 2000; Boon, 2006). In general, because of an emphasis on the inundation period (Braccia and Batzer, 2001), the dry phase of the decomposition process has been overlooked in studies carried out in riverine wetlands (Neiff, 1990). Hydrologic changes can also have substantial effects on the fate and storage of organic matter in riparian wetlands. 
Plant litter is exported from the riparian areas to the river during prolonged and frequent floods, and some fractions are entirely decomposed in the water.

The Ramsar Site Humedales Chaco (from $26^{\circ} 42^{\prime} 56^{\prime \prime} \mathrm{S}$; $58^{\circ} 38^{\prime} 09^{\prime \prime} \mathrm{W}$ to $28^{\circ} 04^{\prime} 28^{\prime \prime} \mathrm{S}$; $59^{\circ} 13^{\prime} 49^{\prime \prime} \mathrm{W}$ ) encompasses part of the low Paraná and Paraguay Rivers floodplain complex along the eastern border of Chaco province (Argentina). The hydrologic connectivity of the floodplain in this site has not been affected by anthropogenic disturbances such as artificial channels or water pollution. Upstream, the land use has a large impact on the forest of the Upper Paraná (Campos, 2004), where the primary vegetation has been lost. Downstream, the mixed gallery forest can be found covering a small area in the delta and has low species richness.

The maximum leaf litterfall in the Paraná River floodplain is either coupled to the inundation phase in palm forests (Poi de Neiff and Casco, 2001) or coincident with drawdown in Palo Bobo forests (Neiff and Poi de Neiff, 1990). In other riverine forests, the decrease in litterfall production has been associated with the decrease in the water level of the river (Aceñolaza et al., 2010). As no further data are available, little is known about the pattern of litter production in the Paraná riverine forest as was indicated for Amazonian várzea floodplain (Piedade et al., 2001).

The hydrologic regime of the Paraná River is irregular, with floods of varying intensity, timing and amplitude (Neiff, 1990). Hydrographs for this river reflect irregularities in the distribution of precipitation over the long-term. Between 1997 and 1998, El Niño Southern Oscillations (ENSO) yielded unusually wet conditions in the Paraná-Paraguay River basin, while the opposite phenomena were recorded between 1999 and 2009. The prolonged droughts led to one of the largest declines in water availability within the floodplain wetland of the Paraná River within the past 30 years. Based on this particular circumstance, the aims of the study were to (1) analyse the pattern of leaf litterfall at community scale in a mixed gallery forest under different combinations of rainfall and hydrologic connectivity with the Paraná River including flood and prolonged drought and (2) compare the breakdown rate of the leaf litter under flooding and dry conditions on the forest floor and in the adjacent oxbow lake. Our hypothesis is that the entry of nutrient-rich waters during floods stimulates the production of the mixed gallery forest leaves, which decompose rapidly under water.

Most food chains in riparian wetlands are detrital, based on the high production of the vegetation (Mitsch and Gosselink, 1993). In the Paraná River floodplain, collectors, which ingest fine particulate organic matter, dominate the invertebrate assemblages (Poi de Neiff et al., 2009). The fish communities contain a high proportion of detritivorous fishes (Winemiller, 2004), which comprise over $50 \%$ of the fish community biomass (Bowen et al., 1984). Understanding the relationship between leaf falls, its processing and extreme hydrologic and climatic conditions are key to assessing the potential effect of hydrologic disturbances (levee construction or impoundment) on riparian wetlands and the detrital food webs.

\section{METHODS}

\section{Study area}

The study area is located on the west bank of the Paraná River, $30 \mathrm{~km}$ downstream from the confluence with the Paraguay River. The alluvial floodplain is $8 \mathrm{~km}$ wide and has several forest types located in different topographic positions along a gradient of connectivity with the river (Figure 1). The area is under humid subtropical climate (Bruniard, 1996, 1999), which is characterized by warm summers and mild winters with low occurrence of frost.

The semideciduous forest type selected was a mixed gallery forest $\left(27^{\circ} 26^{\prime} 07^{\prime \prime} \mathrm{S}, 58^{\circ} 51^{\prime} 33^{\prime \prime} \mathrm{W}\right)$ dominated by Croton urucurana Baill, Inga uraguensis Hook \& Arn, Albizia inundata (Mart.) Barneby \& J.W.Grimes, Cecropia pachystachya Trécul, Enterolobium contortisiliquum (Vell.) Morong, Nectandra angustifolia (Schrad) Nees et Mart, Sapium haematospermum Müll.Arg. and Peltophorum dubium (Spreng.) Taub. In homogeneous areas of mixed gallery forest, litter traps were placed under the tree canopy, with a distance of $10-25 \mathrm{~m}$ between them. We assumed that collection of the traps was independent.

We study a 50-year-old mixed gallery forest with mature trees up to $10-25 \mathrm{~m}$ high with spherical crowns and evergreen foliage. Diameter at breast height ranged from 10 to $60 \mathrm{~cm}$, and anchor roots usually reached $1.10 \mathrm{~m}$ depth, while absorption roots are mainly distributed near the soil surface from 1 to $30 \mathrm{~cm}$ (Neiff, 2005). Tree density of study forest is relatively low (900 trees per hectare), indicating forest maturity. The soil is alluvial with a high proportion of medium-to-fine sand and less than $10 \%$ silt. The accumulated litter thickness locally varies between 1 and $3 \mathrm{~cm}$.

\section{Experimental design and analysis}

We estimated litterfall by using litter traps consisting of $3000-\mathrm{cm}^{2}$ conical nylon mesh bags supported by three $80-\mathrm{cm}$ wooden stakes. Ten traps were placed at 5-m intervals along a transect ( 300 by $20 \mathrm{~m}$ ) parallel to the oxbow axis following the gallery forest. Litterfall was collected biweekly for 4 years that represent different combinations of rainfall and hydrologic connectivity with the Paraná River: 1996-97 (PA), with high hydrological connectivity and abundant rainfall; 1999-2000 (PB), with low hydrological connectivity and abundant rainfall; 2005-2006 (PC), with low hydrological connectivity and low rainfall; 


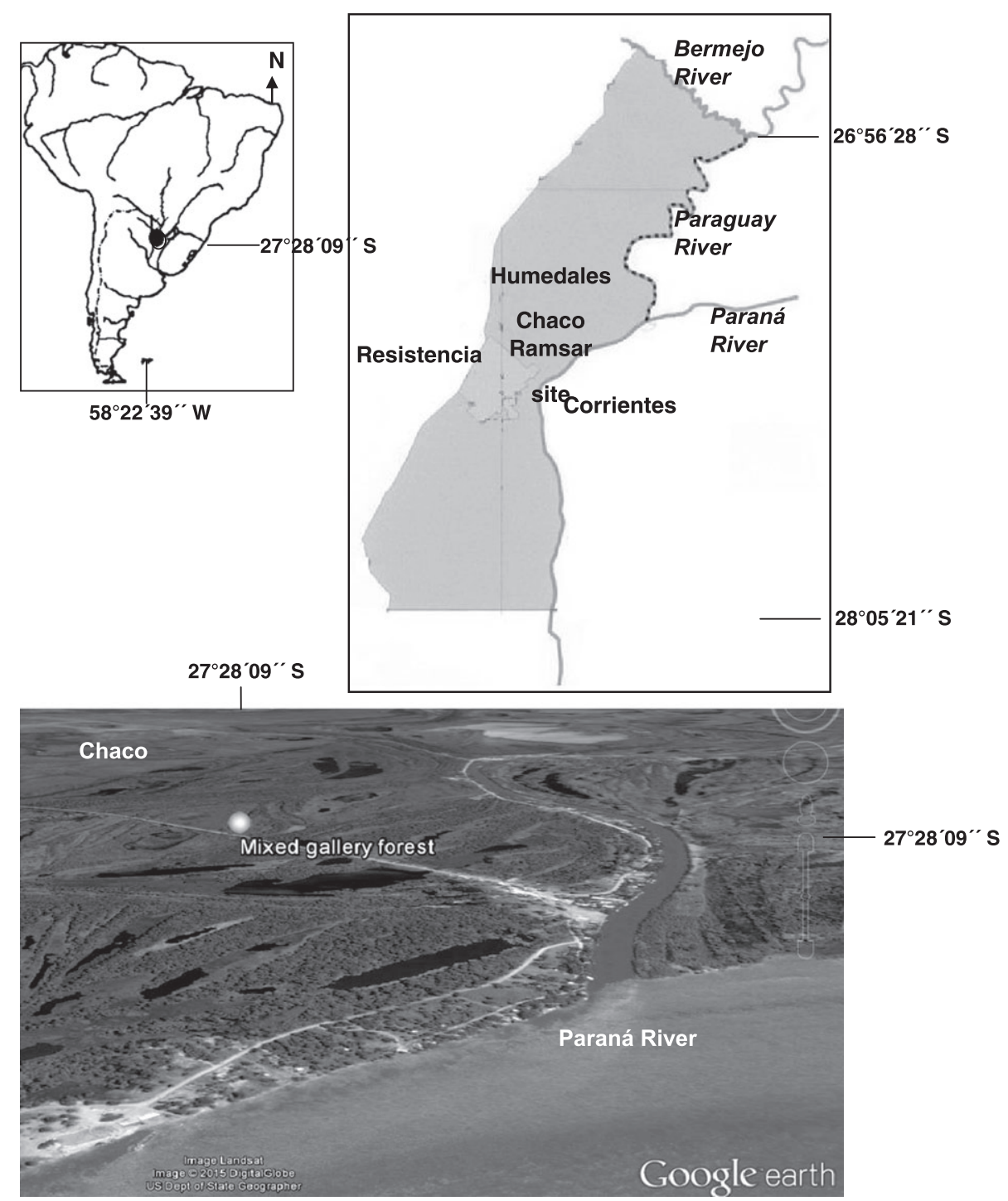

Figure 1. Location of studied site on Paraná River floodplain within the Ramsar Site Humedales Chaco (Argentina).

and 2007-2008 (PD), without the inflow of river water and low rainfall. The leaves were sorted, dried at $105^{\circ} \mathrm{C}$ and weighed.

The leaf litter falls both on the forest floor and in the adjacent oxbow lake. During 2005, the forest floor was covered by $20 \mathrm{~cm}$ of water for 120 days and then remained dried until 2008. The breakdown was measured by the litter bag method during the flooding condition of 2005 in both the forest floor (FFo) and the adjacent oxbow lake (FOx) and during the dry condition of 2006 (DFo) on the forest floor. All experiments started in November to prevent that the effect of wet and dry cycles in the forest floor may be seasonally confounded (Boon, 2006).

Physical and chemical data $(n=15)$ were taken at each condition described earlier. Water temperature and oxygen concentration were measured with a YSI 54A polarographic probe, electrical conductivity was recorded with a YSI 33
SCT device, and pH was measured with a WTW 330/SET-1 digital $\mathrm{pH}$ metre. Water samples were filtered within $1-2 \mathrm{~h}$ of collection on pre-washed Gelman DM-450 (0.45-mm pore) membranes for spectrophotometric analyses of $\mathrm{NH}_{4}^{+}$ (indophenol blue method), $\mathrm{NO}_{3}^{-}+\mathrm{NO}_{2}^{-}$(called $\mathrm{NO}_{3}^{-}$) by $\mathrm{Cd}$ reduction and total phosphorus (molybdenum blue method) with persulfate oxidation (APHA, 1995).

Ten grams of air-dried leaves collected at abscission in the riverine forest was placed in nylon litterbags of $20 \times 20 \mathrm{~cm}$ with a mesh size of $4 \mathrm{~mm}^{2}$. According to the proportion of each species in the litter of the forest, the composition of the litterbags was as follows: C. urucurana $(2.0 \mathrm{~g})$, I. uraguensis $(2.0 \mathrm{~g})$, A. inundata (1.5 g), C.pachystachya (1.5 g), E. contortisiliquum $(1.0 \mathrm{~g})$, N. angustifolia $(1.0 \mathrm{~g})$ and Sapium haematospermum $(1.0 \mathrm{~g})$. Five replicate bags were incubated at 7, 30, 60 and 120 days in FFo, Fox and DFo, for a total of 60 litter bags. 
After each incubation date, one set of bags was removed for each FFo, FOx and DFo condition, and each bag was transported separately in a plastic bag to the laboratory. In the laboratory, leaves were washed and dried to constant weight (at $105^{\circ} \mathrm{C}$ ). Conversion factors for dry weight and air-dried mass were calculated to estimate the initial dry weight in the bags. We calculated decay rates ( $k$ /day) under flooded and dry conditions using an exponential decay model (Webster and Benfield, 1986).

We also collected leaves from each site to determine nutrient contents. These leaves were dried at $60^{\circ} \mathrm{C}$ and subjected to nitrogen (macro Kjeldähl method), phosphorus (AOAC, 1990) and fibre content analysis (Ankom Fiber Analyzer). The results are expressed as percentages of dry weight.

Daily hydrometric information provided by the Dirección Nacional de Vías Navegables y Puertos at the Corrientes gauge was used to analyse water level fluctuations of the Paraná River.

According to Neiff (1996), a pulse is defined as the time between the beginning of the flooding and the end of the isolated phase for a topographic point of the floodplain. Five components of the flow regimen regulated ecological processes: magnitude, frequency, duration, timing and rate of change of hydrologic condition for different floodplain rivers (Neiff, 1990, Poff et al., 1997). We calculated the frequency of pulses, number of flooding days and number of emergent soil days based on the overflow level of mixed gallery forest, assuming that this level represents the beginning of the floods.

A mean fluvial connectivity quotient (FCQ) (Neiff and Poi de Neiff, 2003) was calculated from the FCQ for each pulse divided by the number of pulses as follows: $F C Q=$ number of flooded days/number of non-flooded days. Pulse attributes were analysed using PULSO 1.05 software (Neiff and Neiff, 2004).

Rainfall data for the study period were provided by the station Colonia Benítez of the Instituto Nacional de Tecnología Agropecuaria, Chaco province, Argentina.

A single-factor analysis of variance (ANOVA) with post hoc Tukey tests was used to test for significant differences in leaf litterfall among periods. An analysis of covariance (ANCOVA) was used to test the relationship between the litter dry weight remaining and the incubation dates under different conditions (FFo, FOx and DFo). LSD Fisher Alfa was used as post test to compare means using INFOSTAT software (Di Rienzo et al., 2012).

To compare the loss of dry mass among different conditions, we used forward stepwise multiple regressions between the decay coefficient of the mixed gallery forest ( $k$ as dependent variable) in FFo, FOx and DFo, and dissolved oxygen content, $\mathrm{pH}$, electrical conductivity and water temperature during the incubation time.

\section{RESULTS}

During the wet period (PA), the mixed gallery forest was connected to the main channel of the Paraná River for 115 days (Table I) and received five pulses that started in April, October, November and December 1996 and January 1997. In each pulse, the forest was connected with the river during 11, 28, 5, 19 and 52 days. This period is the beginning of the ENSO event (1997-1998), when the water level of the Paraná River reached $8.39 \mathrm{~m}$ at the Corrientes gauge. Since 1999, the water level has fluctuated less than $6.55 \mathrm{~m}$, with a minimum of $1.40 \mathrm{~m}$ (Figure 2). During PB and PC, the river exceeded overflow level only one time during July 1999 and November 2005, respectively (Table I) and the mixed gallery forest was disconnected to the Paraná River for 359 and 358 days, respectively (Figure 2). During the drought period (PD), without the inflow of river water and low rainfall, the forest remained 366 days with the emerged soil (Table I). The hydrologic connectivity decreased during PB, PC and PD (Table I).

According to mean monthly rainfall data for the periods April 1996-March 1997, April 1999-March 2000, September 2005-August 2006 and July 2007-June 2008, the rainy season occurred during spring-summer or during autumn, whereas the dry season was concentrated in winter (Figure 2). The annual precipitation was lowest in PD (Table II). The highest number of consecutive days without rain ranged between 42 in PA and $46 \mathrm{~PB}$. However, the highest number of consecutive days without rain in $\mathrm{PD}$ (29) occurred several times during the study period. The mean monthly wind velocity varied between 5.3 and $9.4 \mathrm{~km} \mathrm{~h}^{-1}$ (Table II), and the maximum values (between

Table I. Hydrologic connectivity of the mixed gallery forests during the study periods.

\begin{tabular}{|c|c|c|c|c|}
\hline & PA & PB & $\mathrm{PC}$ & PD \\
\hline Topographic position (m.a.s.l) & 47.54 & 47.54 & 47.54 & 47.54 \\
\hline Overflowing level (m) & 5.15 & 5.15 & 5.15 & 5.15 \\
\hline Frequency of pulses & 5 & 1 & 1 & 0 \\
\hline Number of days with hydrologic connectivity & 115 & 8 & 8 & 0 \\
\hline Number of emerged soils days & 251 & 359 & 358 & 366 \\
\hline Fluvial connectivity quotient & 2.31 & 0.022 & 0.022 & 0 \\
\hline
\end{tabular}




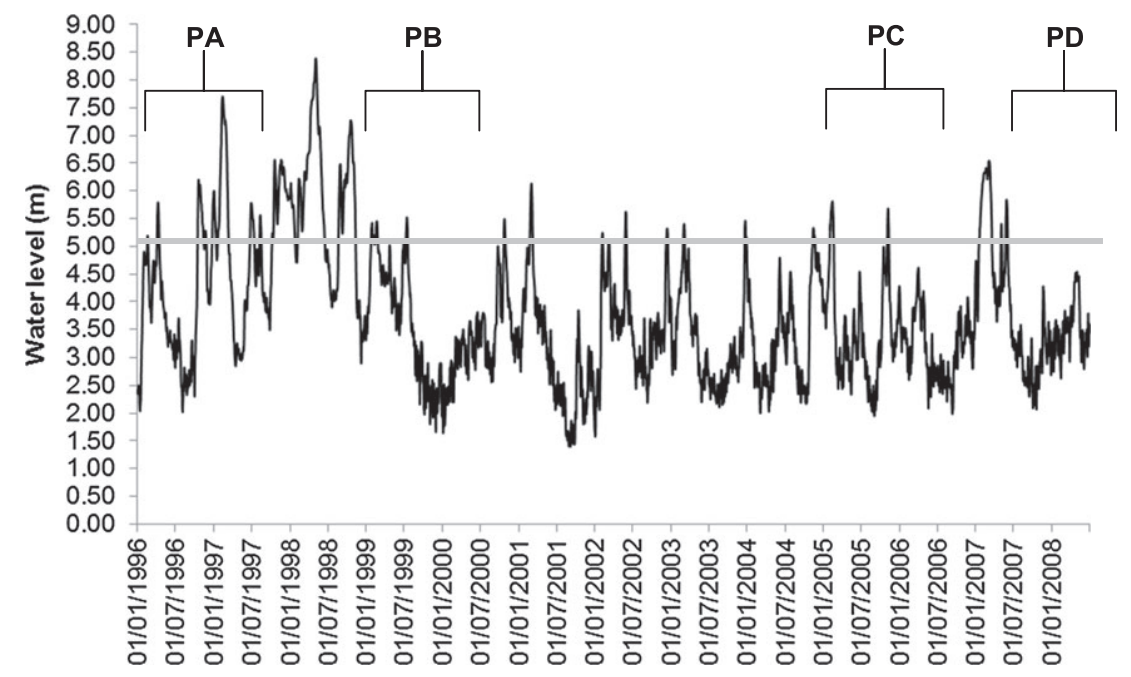

Figure 2. Water level fluctuations of the Paraná River at Puerto Corrientes between 1996 and 2008. The mixed gallery forest was connected with the river above the level indicated by horizontal line. PA: Period A, with high hydrological connectivity and abundant rainfall; PB: Period B, with hydrological connectivity and abundant rainfall; PC: Period C, Period C, low hydrological connectivity and low rainfall; PD: Period D, without the inflow of river water and low rainfall.

Table II. Cumulative annual litterfall and precipitation, and mean monthly ( \pm 1 SD) environmental variables during different conditions: with the inflow of river water and abundant rainfall (PA); without the inflow of river water and abundant rainfall (PB); with the inflow of river water and low rainfall (PC); and without the inflow of river water and low rainfall (PD).

\begin{tabular}{lrrrr}
\hline & \multicolumn{1}{c}{ PA } & PB & PC & PD \\
\cline { 2 - 5 } & Apr 1996-Mar 1997 & Apr 1999-Mar 2000 & Sep 2005-Aug 2006 & Jul 2007-Jun 2008 \\
\hline Litterfall (tn ha ${ }^{-1} \mathrm{yr}^{-1}$ ) & & 11.15 & 10.42 & 14.34 \\
Annual precipitation (mm) & 1744 & 1071 & 896 & $21 \pm 6.39$ \\
Temperature $\left({ }^{\circ} \mathrm{C}\right)$ & $22 \pm 8.65$ & $21.1 \pm 4.25$ & $21.7 \pm 4.51$ & $57.1 \pm 10.82$ \\
Relative heliophany (\%) & $60.1 \pm 7.76$ & $57.3 \pm 8.21$ & $63.9 \pm 7.74$ & $6.1 \pm 2.15$ \\
Wind velocity at 2 m (km) & $9.4 \pm 1.34$ & $5.3 \pm 1.15$ & $5.6 \pm 1.18$ & $69.5 \pm 3.80$ \\
Relative moisture (\%) & $74.4 \pm 5.66$ & $72.7 \pm 7.78$ & $70.1 \pm 7.79$ & 3.7 \\
Evapotranspiration (mm) & 3.8 & 3.4 & -0.7 & -1.1 \\
Precipitation-evapotranspiration ratio (mm) & -0.3 & -0.4 & & \\
\hline
\end{tabular}

14.5 and $24.8 \mathrm{~km} \mathrm{~h}^{-1}$ ) were recorded in September 2005 and January 1997. Temperature, relative heliophany, wind velocity, relative moisture and evapotranspiration (Table II) were similar within the different periods. The ratio between precipitation and evapotranspiration increased in PC and PD (Table II).

The water in the inundated floor forest was acidic (6.0-6.5) and contained low dissolved oxygen $\left(1.3 \pm 0.15 \mathrm{mgl}^{-1}\right)$ and low nitrogen content $\left(7.9 \pm 0.21 \mu \mathrm{gl}^{-1}\right)$. The experiment in the oxbow lake was conducted under permanent slow flowing water, where $\mathrm{pH}$ values were slightly acidic or neutral $(6.5-7.1)$. Water temperatures were generally high $\left(22-26^{\circ} \mathrm{C}\right)$, and electrical conductivity ranged between 90 and $161 \mu \mathrm{S} \mathrm{cm}^{-1}$. Dissolved oxygen concentrations varied between 4.7 and $6.2 \mathrm{mgl}^{-1}$, and nitrogen $\left(\mathrm{NO}_{3}^{-}\right)$content reached $154 \mu \mathrm{gl}^{-1}$. During the dry condition, the $\mathrm{pH}$ of the forest floor was acidic, and the temperature ranged between 19.7 and $22^{\circ} \mathrm{C}$.

\section{Litterfall}

The total annual leaf litterfall were 8.97, 11.15, 10.42 and $14.43 \mathrm{tn} \mathrm{ha}^{-1} \mathrm{yr}^{-1}$ for PA, PB, PC and PD, respectively. During the four study periods, leaf fall in the mixed gallery forest occurred throughout the year (Figure 3). Differences in the mean monthly leaf fall rate between periods (PA, PB, PC and $\mathrm{PD})$ were not significant (ANOVA, $p>0.155$ ). Monthly leaf fall showed a similar pattern in the four study periods, with $20.77 \%, 19.99 \%, 17.21 \%$ and $18.52 \%$ of total annual leaf production for the month of peak production. Maximum average monthly litterfall rates of 7.33 and $8.01 \mathrm{~g} \mathrm{~m}^{2}$ day $^{-1}$ (Figure 3) were recorded during August (PB) and September (PD). At PA and PC, most leaves fell during October (Figure 3).

\section{Litter breakdown}

Percentages of nitrogen, phosphorus and lignin in the litter of mixed leaves at abscission were $1.53 \pm 0.205,0.37 \pm 0.028$ and $23.4 \pm 0.8$, respectively. 

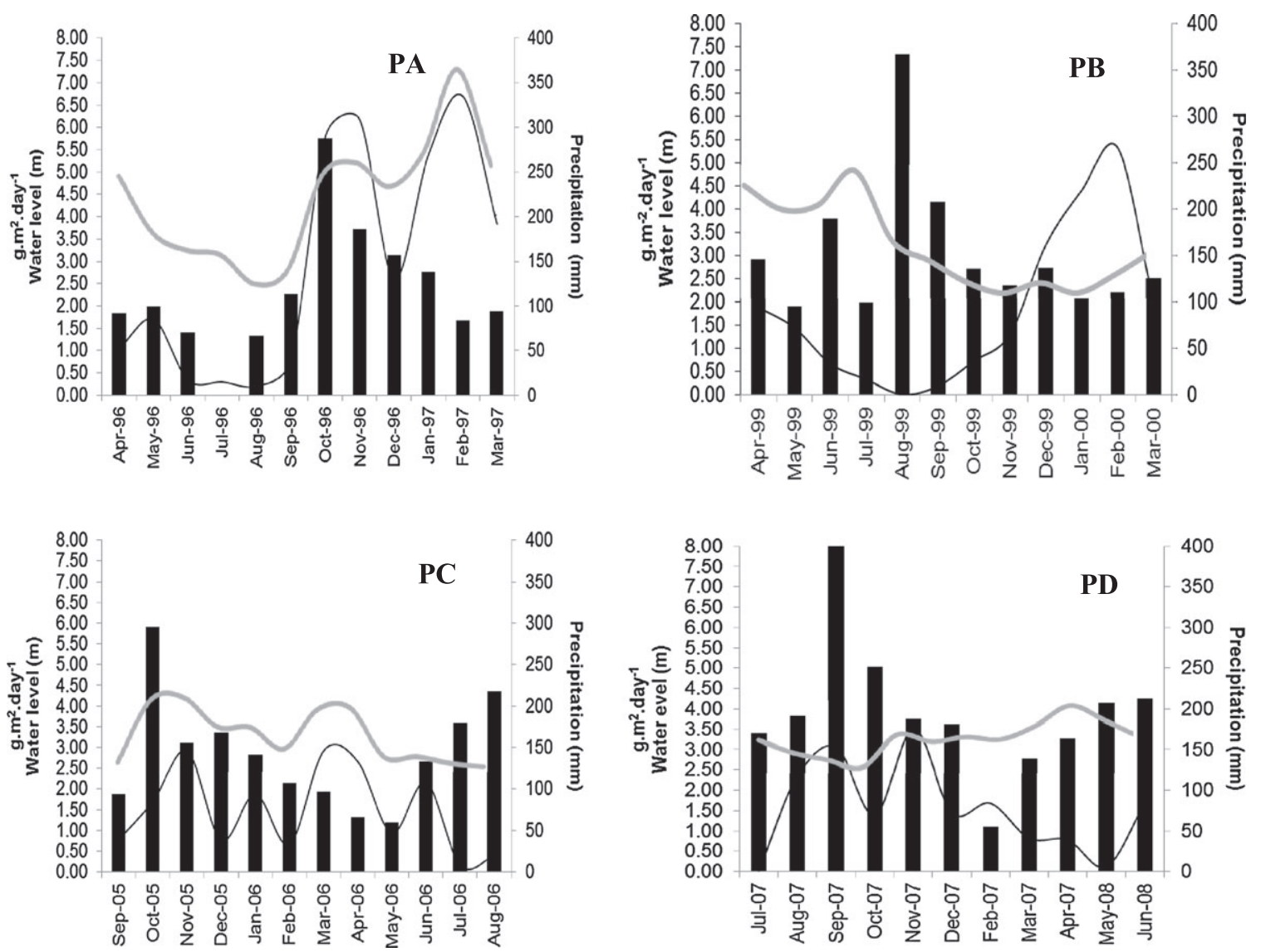

Figure 3. Average monthly litterfall rate $\left(\mathrm{g} \mathrm{m}^{2} \mathrm{day}^{-1}\right)$ of the mixed gallery forest with the inflow of river water and abundant rainfall (PA), without the inflow of river water and abundant rainfall $(\mathrm{PB})$, with the inflow of river water and low rainfall $(\mathrm{PC})$ and without the inflow of river water and low rainfall (PD). Average monthly water level (m) of Paraná River and precipitation $(\mathrm{mm})$ are represented by grey and black lines, respectively.

The relationship between dry weight remaining and incubation dates (Figure 4) adjusted to a linear regression

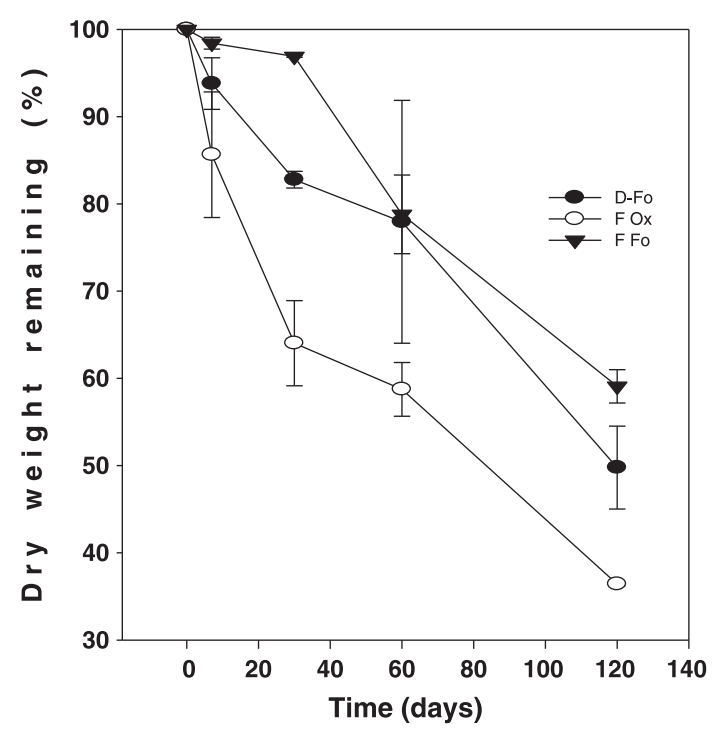

Figure 4. Remaining dry weight of the mixed gallery forest on the forest floor $(\mathrm{FFo})$ and in the oxbow lake (FOx) during the flooding condition and on the forest floor during the dry condition (DFo). with $R^{2}$ of $0.84,0.88$ and 0.95 for DFo, FOx and FFo, respectively. The comparison of decomposition rates of mixed gallery forest under different conditions using ANCOVA showed that there was no interaction between curves and the intercepts differed significantly between conditions $(F=122.25, p<0.0001)$. The post test indicated a different litter for each experiment. Thus, mixed gallery forest leaves decomposed fastest in the oxbow lake under permanently inundated conditions (FOx), with an estimated half-life of 81.51 days (Figure $4, k=0.008502$ ). The estimated time for $50 \%$ decomposition of leaf litter on the floor forest was longer at FFo (161.2 days, $k=0.0043)$ than at DFo (119.5 days, $k=0.0058$ ).

For all variables measured over time, there was a significant effect of dissolved oxygen on decay rates although the model explains only $59 \%$ of the variation.

\section{DISCUSSION}

Mixed gallery forests produce higher annual leaf litterfall than other riverine forests in the study area, for example Tessaria integrifolia, which are located at a low topographic 
position with more frequent flooding $\left(6.43 \mathrm{tnha}^{-1} \mathrm{yr}^{-1}\right.$, Neiff and Poi de Neiff, 1990) and Copernicia alba, located at a high topographic position (0.97 and $1.83 \mathrm{tn} \mathrm{ha}^{-1} \mathrm{yr}^{-1}$ ). These values are higher than those found at population level by Aceñolaza et al. (2010) in a mixed gallery forest located downstream.

The amount annual leaf litterfall in the mixed gallery forest studied was similar to that found for other tropical flooded forests in the Amazonian floodplain (Franken et al., 1979; Piedade et al., 2001). Mitsch and Gosselink (1993) reported amounts of leaf litterfall between 4.20 and $5.74 \mathrm{tn} \mathrm{ha}^{-1} \mathrm{yr}^{-1}$ for selected riparian-forested wetlands of the USA. In prolonged dry conditions, the annual leaf litterfall is lower than the annual production of tropical forests (17 tn ha ${ }^{-1} \mathrm{yr}^{-1}$, Frangi and Lugo, 1985).

Our results do not support the subsidy-stress hypothesis that the highest forest litter production occurs with periodic floods of short duration because of subsidies of nutrient. The importance of nutrient inputs to the floodplain during floods the Paraná River has been demonstrated for the study area (Carignan and Neiff, 1992). However, monthly leaf fall of the riverine forest was similar among periods with and without floods, and its annual production increases during the prolonged drought. This result is consistent with other study by Conner et al. (1981) in which less frequent flooding resulted in higher annual forest biomass production $\left(17.8 \mathrm{tn} \mathrm{ha}^{-1} \mathrm{yr}^{-1}\right)$ than permanently flooded conditions $\left(8.87 \mathrm{tn} \mathrm{ha}^{-1} \mathrm{yr}^{-1}\right)$. In the low Paraguay River, from 1981 to 1984 in an ENSO event, the leaves of the floodplain forest were completely lost during unusually prolonged flood events that caused 1000 days of flooded soil (Neiff, 2005). However, during the study period, this situation was not recorded.

Regardless of the seasonal pattern of rainfall and hydrological regime of each study period, the peak of litterfall was recorded between August and October. According to these results, the leaf fall of the riverine forest studied does not occur at random during the year but is most likely also regulated by endogenous factors. Reich (1995) suggested that the timing of leaf fall is generally determined by the tree water status, which is a function of the interaction between the water status of the environment and the structural and functional state of the tree (endogenous controls).

Because the annual leaf fall depends on the seasonal pattern of rainfall and hydrological connectivity but its seasonal pattern presents no changes for different periods with decreasing conditions of rainfall and hydrological connectivity, our first hypothesis has to be partially accepted.

Generally, mass loss from decaying leaf litter is faster in aquatic systems because of enhanced leaching and microbial metabolism (Graça, 2001; Langhans and Tockner, 2006; Boon, 2006). In many floodplain rivers (Boulton, 1991;
Mathooko, 1995; Furch and Junk, 1997; Neatrour et al., 2004; Padial and Thomaz, 2006) and in a temperate river in which litter was moved between dry and wet conditions (Langhans and Tockner, 2006), loss of mass over time was fastest under permanently inundated conditions. In our study, the breakdown rates differed significantly between the three conditions, but the lowest decay coefficient was recorded in the flooded forest floor and not on the dry forest floor. As a consequence, the second hypothesis that the decomposition rate of leaf litter is faster during the flooding condition than under dry conditions is partially accepted.

Leaf breakdown is influenced by factors related to the condition where the processes occur, such as $\mathrm{pH}$ and oxygen content and nutrient concentration (Webster and Benfield, 1986). The significantly slower litter decay rates of the mixed gallery forest on the forest floor is due, in part, to the significantly lower oxygen content compared with the flooding condition in the oxbow lake and the dry forest floor. However, different studies indicated that the effect of dissolved oxygen is small in comparison with the effect of other factors such as temperature (Webster and Benfield, 1986). In wet subtropical climates, temperature is less constraining, and the decomposition depends on other factors (Coûteaux et al., 1995).

The leaf breakdown rates of the mixed gallery forest were slower than the rates reported for different riverine forests of the Paraná River (Neiff and Poi de Neiff, 1990; Capello et al., 2004; Galizzi and Marchese, 2007) and for a tropical floodplain forest (Rueda Delgado et al., 2006). Leaf litter quality (e.g. nitrogen content and L:N ratio) and environmental variables are important factors regulating leaf litter breakdown in Paraná River floodplain wetlands (Poi de Neiff et al., 2006). A similar decay rate of a mixed gallery leaf litter was obtained in another oxbow lake (Poi de Neiff et al., 2006) during the period PB of this study.

Regular floods are natural occurrences that do not affect the leaf production of the Parana mixed gallery forest, and the leaf processing depends on the oxygen concentrations. Thus, prolonged droughts led to high annual leaf production, which is mainly processed within the riverine forest. Under this particular circumstance, the riverine forest is a highly retentive system which tends towards accumulation of soil organic matter.

\section{ACKNOWLEDGEMENTS}

We are very grateful to Alonso Ramírez (Instituto para Estudios de Ecosistemas Tropicales-ITES-Universidad de Puerto Rico) for critically reading manuscript and offering many helpful comments. This study was supported by Projects PIP 11220100100486 and PIP $11420100100215-$ Consejo Nacional de Investigaciones Científicas y Técnicas (CONICET) 


\section{REFERENCES}

Abelho M. 2001. From litterfall to breakdown in streams: a review. The Scientific World 1: 656-680.

Aceñolaza P, Zamboni L, Rodríguez E, Gallardo JF. 2010. Litterfall production in forests located at the pre-delta area of the Paraná River (Argentina). Annals Forest Science 67: 1-10.

Allan JD, Castillo MM. 2007. Stream Ecology. Structure and Function of Running Waters. Springer: Dordrecht.

AOAC -Association of Official Analytical Chemists-. 1990. Phosphorus in Animal Feed, Photometric Methods. Arlington: AOAC.

APHA- American Public Health Association-. 1995. Standard Methods for the Examination of Water and Wastewater. APHA: Washington.

Boon PI. 2006. Biogeochemistry and bacterial ecology of hydrologically dynamic wetlands. In Ecology of Freshwater and Estuarine Wetlands, Batzer DP, Sharitz R (eds). University of California Press: Berkeley; $115-176$.

Boulton AJ. 1991. Eucalypt leaf decomposition in an intermittent stream in south-eastern Australia. Hydrobiologia 211: 123-136.

Bowen SH, Bonetto AA, Ahlgren MO. 1984. Microorganisms and detritus in the diet of a typical neotropical riverine detritivore, Prochilodus platensis (Pisces: Prochilodontidae). Limnology and Oceanography 29: $120-1122$.

Braccia A, Batzer DP. 2001. Invertebrates associated with woody debris in a southeastern forested floodplain wetland. Wetlands 21: 18-31.

Brinson MM. 1990. Riverine forests. In Forested Wetlands, Lugo AE, Brinson MM, Brown S (eds). Elsevier: Amsterdam; 87-142.

Bruniard ED. 1996. Geografía de los climas y de las formaciones vegetales. Aporte para un modelo fitoclimático mundial. Las zonas térmicas y la vegetación natural. Editorial Universitaria de la Universidad Nacional del Nordeste. 330 p.

Bruniard ED. 1999. Clima. Caracterización climática del Nordeste de la Provincia de Corrientes (Propiedades: Puerto Valle, Garruchos y El Ciríaco). En: Evaluación del Impacto Ambiental de los Predios Forestales de SHELL C.A.P.S. A. Forestal. Medio Ambiente. 268 p.

Budke JC, Jarenkow JA, Teixeira de Oliveira-Filho A. 2010. Intermediary disturbance increases tree diversity in riverine forest of Southern Brazil. Biodiversity and Conservation 19: 2371-2387.

Campos JB. 2004. Spatial characterization of the vegetation. In The Upper Paraná River and Its Floodplain, Thomaz SM, Agostinho AA, Hahn NS (eds). Blackhuys Publishers: Leiden; 309-380.

Capello S, Marchese M, Ezcurra de Drago I. 2004. Descomposición y colonización por invertebrados de hojas de Salix humboldtiana en la llanura aluvial del río Paraná Medio. Amazoniana 18: 125-143.

Carignan R, Neiff JJ. 1992. Nutrient dynamics in the flood plain ponds of the Paraná River (Argentina) dominated by the water hyacinth Eichhornia crassipes. Biogeochemistry 17: 85-121.

Conner WH, Gosselink JG, Parrondo RT. 1981. Comparison of the vegetation of three Louisiana swamp sites with different flooding regimes. American Journal of Botany 63: 320-331.

Coûteaux MM, Bottner P, Björn B. 1995. Litter decomposition, climate and litter quality. Tree 10: 63-66.

de Assis RL, Wittmann F. 2011. Forest structure and tree species composition of the understory of two central Amazonian várzea forests of contrasting flood heights. Flora 206: 251-260.

Di Rienzo JA, Casanoves F, Balzarini MG, González L, Tablada M, Robledo CW. 2012. InfoStat versión 2012. Grupo InfoStat, FCA, Universidad Nacional de Córdoba, Argentina. URL http://www. infostat.com.ar

Frangi JL, Lugo AE. 1985. Ecosystem dynamics of a subtropical floodplain forest. Ecological Monographs 55: 351-369.

Franken M, Irmler U, Klinge DH. 1979. Litterfall in inundation, riverine and terra firme forests of Central Amazonia. Tropical Ecology 20: $225-235$.

Furch K, Junk WJ. 1997. The chemical composition, food value and decomposition of herbaceous plants and leaf litter of the floodplain forest. In The Central Amazonian Floodplain: Ecology of a Pulsing System, Junk WJ (ed). Springer: Berlin; 187-205.

Galizzi MC, Marchese M. 2007. Descomposición de hojas de Tessaria integrifolia (Asteraceae) y colonización por invertebrados en un cauce secundario del río Paraná. Interciencia 32: 535-540.
Graça MAS. 1993. Patterns and processes in detritus-based stream system. Limnologica 23: 107-114.

Graça MAS. 2001. The role of invertebrates on leaf litter decomposition in streams-a review. International Review of Hydrobiology 86: 383-393.

Langhans S, Tockner K. 2006. The role of timing, duration, and frequency of inundation in controlling leaf litter decomposition in a riverfloodplain ecosystem (Tagliamento, northeastern Italy). Oecologia 147: 501-509.

Marchetti ZY, Aceñolaza PG. 2012. Pulse regime and vegetation communities in fluvial systems: the case of the Paraná River floodplain, Argentina. Flora 207: 795-804.

Mathooko JM. 1995. The retention of plant coarse particulate organic matter (CPOM) at the surface of the wet-store and dry-store zones of the Njoro River, Kenya. African Journal of Ecology 33: 159.

Megonigal JP, Conner WH, Kroeger S, Sharitz RR. 1997. Aboveground production in southeastern floodplain forests: a test of the subsidy-stress hypothesis. Ecology 78: 370-384.

Mitsch WJ, Gosselink JG. 1993. Wetlands. Van Nostrand Reinhold: New York.

Naiman RJ, Décamps N, McClain ME. 2005. Riparia: Ecology, Conservation, and Management of Streamside Communities. Elsevier Academic Press: San Diego.

Neatrour M, Webster JR, Benfield EF. 2004. The role of floods in particulate organic matter dynamics of a southern Appalachian river floodplain ecosystem. Journal of the North American Benthological Society 23: 198-213.

Neiff JJ. 1990. Ideas para la interpretación ecológica del Paraná. Interciencia 15: 424-441.

Neiff JJ. 1996. Large rivers of South America: toward the new approach. Verhandlungen des Internationalen Verein Limnologie 26: 167-180.

Neiff JJ. 2005. Bosques fluviales de la cuenca del Paraná. In Ecología y Manejo de los bosques de Argentina, Arturi MA, Frangi JL, Goya JF (eds). Editorial Universidad de La Plata: La Plata; 1-26.

Neiff JJ, Neiff M. 2004. Pulso. Software diseñado para estudiar fenómenos recurrentes en el tiempo. www.neiff.com.ar.

Neiff JJ, Poi de Neiff A. 1990. Litterfall, leaf decomposition and litter colonization of Tessaria integrifolia in the Paraná River floodplain. Hydrobiologia 203: 45-52.

Neiff JJ, Poi de Neiff A. 2003. Connectivity processes as a basis for management of aquatic plants. In Ecologia e Manejo de Macrófitas Aquáticas, Thomaz SM, Bini LM (eds). Editora da Universidade Estadual de Maringá: Maringá; 127-144.

Padial AA, Thomaz SM. 2006. Effects of flooding regime upon the decomposition of Eichhornia azurea (Sw.) Kunth measured on a tropical, flow-regulated floodplain (Paraná River, Brazil). River Research and Applications 22: 791-801.

Piedade MTF, Worbes M, Junk WJ. 2001. Geo-ecological controls on elemental fluxes in communities of higher plants in Amazonian floodplains. In The Biogeochemistry of the Amazon Basin, McClain ME, Victoria RL, Richey JE (eds). Oxford University Press: Oxford; 209-234.

Poff NL, Allan JD, Bain MB, Karr JR, Prestegaard KL, Richter BD, Sparks RE, Stromberg JC. 1997. The natural flow regime. BioScience 47: 769-784.

Poi de Neiff A, Casco SL. 2001. Caída de hojas, descomposición y colonización por invertebrados en palmares de la planicie de inundación del río Paraná (Chaco, Argentina). Interciencia 26: 567-571.

Poi de Neiff A, Neiff JJ, Casco SL. 2006. Leaf litter decomposition in three wetland types of the Paraná River floodplain. Wetlands 26: $558-566$.

Poi de Neiff A, Galassi ME, Franceschini MC. 2009. Invertebrate assemblages associated with leaf litter in three floodplain wetlands of the Paraná River. Wetlands 29: 896-906.

Pozo J, González E, Diez JR, Molinero J, Elosegi A. 1997. Inputs of particulate organic matter to streams with different riparian vegetation. Journal of the North American Benthological Society 16: 602-611.

Reich PB. 1995. Phenology of tropical forests: patterns, causes and consequences. Canadian Journal of Botany 73: 164-174.

Rueda Delgado G, Wantzen KK, Beltrán Tolosa M. 2006. Leaf litter decomposition in an Amazonian floodplain stream: effects of seasonal hydrological changes. Journal of the North American Benthological Society 25: 233-249. 
Tabacchi E, Correll D, Hauer R, Pinay G, Planty-Tabacchi A, Wissmar R. 1998. Development, maintenance and role of riparian vegetation in the river landscape. Freshwater Biology 40: 497-516.

Tockner K, Malard F, Ward JV. 2000. An extension of the flood pulse concept. Hydrological Process 14: 2861-2883.

Wantzen KM, Yule CM, Mathooko JM, Pringle CM. 2008. Organic matter processing in tropical streams. In Tropical Streams Ecology, Dudgeon D (ed). Elsevier: London; 43-64.
Webster JR, Benfield EF. 1986. Vascular plant breakdown in freshwater ecosystems. Annual Review Ecological System 17: 567-594.

Winemiller KO. 2004. Floodplain river food webs: generalizations and implications for fisheries management. In Proceedings of the Second International Symposium on the Management of Large Rivers for Fisheries, Welcomme RL, Petr T (eds). Mekong River Commission, Phnom Penh: Cambodia; 285-309. 